
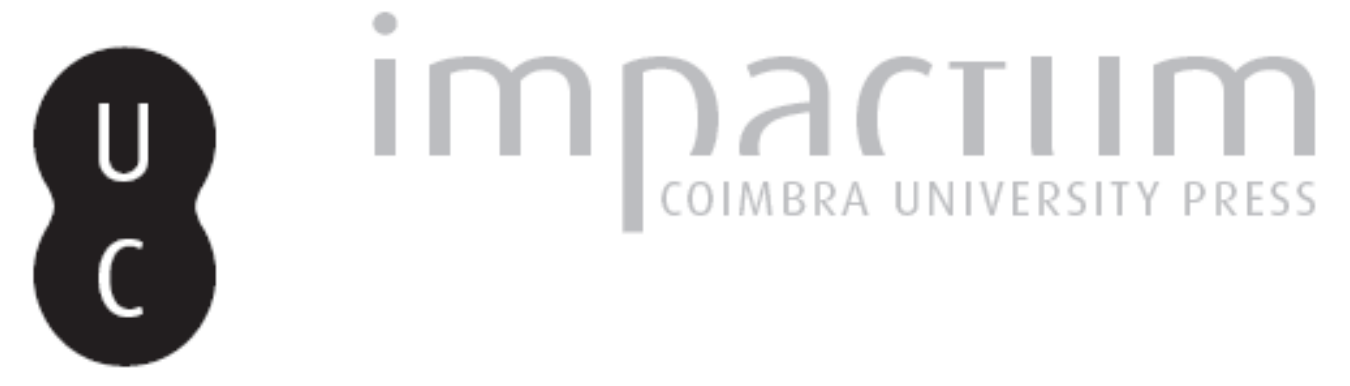

\title{
El Conde de Aranda y la Revolución Francesa
}

Autor(es): $\quad$ Ferrer Benimeli, José A.

Publicado por: Imprensa da Universidade de Coimbra

URL persistente:

URl:http://hdl.handle.net/10316.2/43761

DOI:

DOI:https://doi.org/10.14195/2183-8925_10_2

Accessed : $\quad$ 26-Apr-2023 06:57:39

A navegação consulta e descarregamento dos títulos inseridos nas Bibliotecas Digitais UC Digitalis, UC Pombalina e UC Impactum, pressupõem a aceitação plena e sem reservas dos Termos e Condições de Uso destas Bibliotecas Digitais, disponíveis em https://digitalis.uc.pt/pt-pt/termos.

Conforme exposto nos referidos Termos e Condições de Uso, o descarregamento de títulos de acesso restrito requer uma licença válida de autorização devendo o utilizador aceder ao(s) documento(s) a partir de um endereço de IP da instituição detentora da supramencionada licença.

Ao utilizador é apenas permitido o descarregamento para uso pessoal, pelo que o emprego do(s) título(s) descarregado(s) para outro fim, designadamente comercial, carece de autorização do respetivo autor ou editor da obra.

Na medida em que todas as obras da UC Digitalis se encontram protegidas pelo Código do Direito de Autor e Direitos Conexos e demais legislação aplicável, toda a cópia, parcial ou total, deste documento, nos casos em que é legalmente admitida, deverá conter ou fazer-se acompanhar por este aviso.

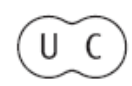


REVISTA DE HISTORIA DAS IDEIAS IO
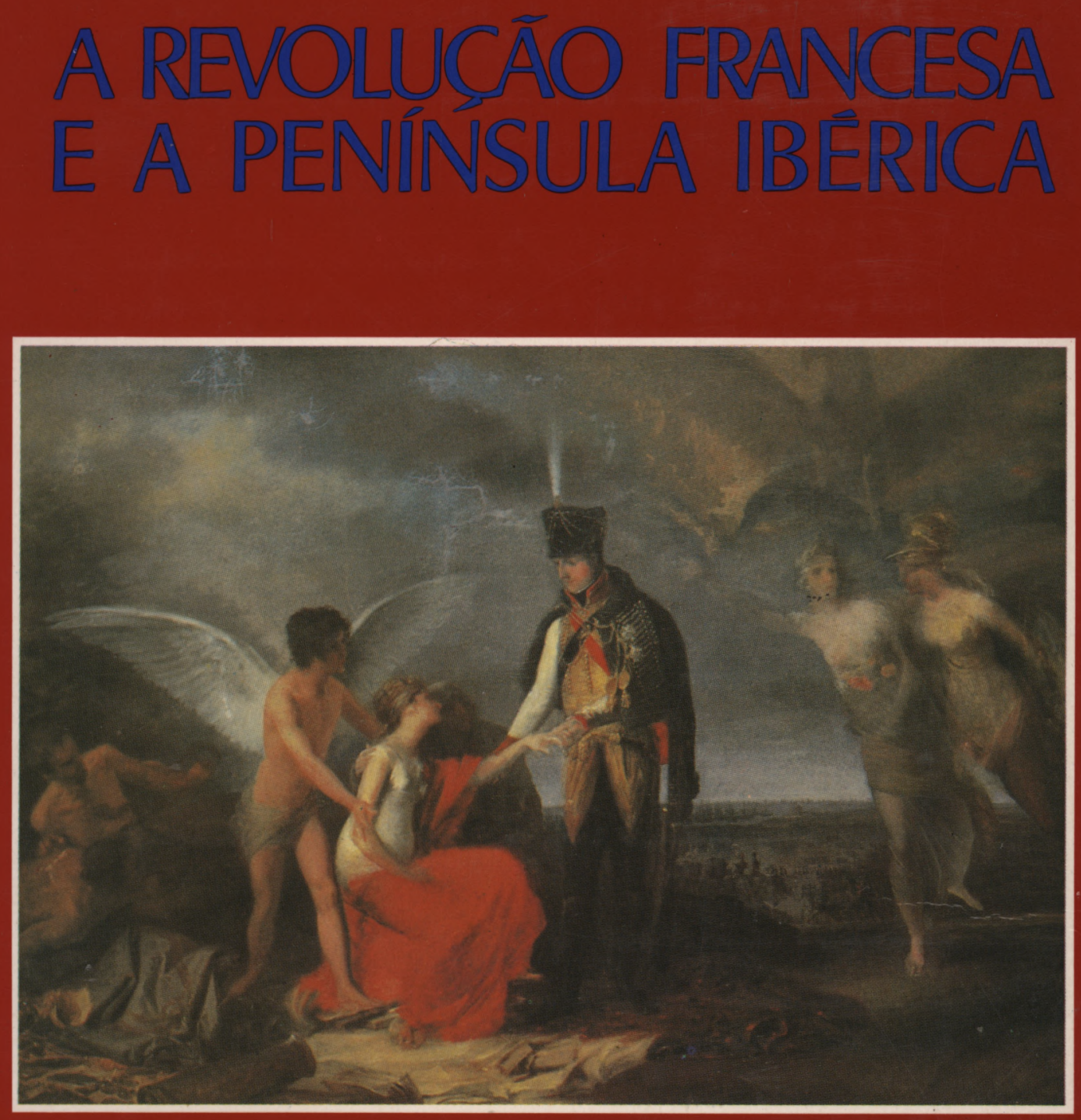

INSTITUTO DE HISTÖRIA E TEORIA DAS IDEIAS FACULDADE DE LETRAS 
JOSÉ A. FERRER BENIMELI *

\section{EL CONDE DE ARANDA Y LA REVOLUCIÓN FRANCESA}

La actividad del conde de Aranda en su último período de vida política, cuando en 1792 , a los 73 años de edad, fue nombrado Decano del recién restablecido Consejo de Estado y primer Secretario de Estado $\left({ }^{(}\right)$, se centró en la difícil situación internacional planteada por la Revolución Francesa, que llevaría finalmente a la declaración de guerra entre España y la Convención francesa, más conocida con el nombre de guerra de los Pirineos (1793-95), y que tanto en los preliminares como en su desarrollo sirvió para que el conde pusiera nuevamente de manifiesto su fuertemente arraigado espíritu militar (2). Aquí es importante resaltar que nos encontramos ante uno más de tantos tópicos con que se suele deformar la figura de Aranda, es a saber: el de hacerle «amigo» de los revolucionarios franceses.

Pero lo que pensaba Aranda de tales «amigos» quedó bien patente en la crisis política del 10 de agosto de 1792, en la que se decidió declarar la guerra contra la Francia revolucionaria, y donde los definió con los no muy cariñosos epítetos de «rebeldes» y «fanáticos gallos», ccntra los que incluso llegó a preparar un ataque bien pensado; proyecto que mantuvo el viejo

* Universidad de Zaragoza.

(1) Reales Decretos fechados el 28 de febrero de 1792. Ambos decretos fueron concebidos según los deseos manifestados por el conde de Aranda a los Reyes españoles, en presencia de Godoy, deseos que, en realidad, fueron las condiciones que impuso para la aceptación del cargo que le ofrecieron para sustituir a Floridablanca.

(2) Sobre el carácter militar de Aranda cfr. R. y Olaechea, J.A. Ferrer Benimeli, El Conde de Aranda (Mito y realidad de un politico aragonés), Zaragoza, Librería General, 1978, 2 vols. 


\section{Revista de História das Ideias}

conde aragonés con ilusión, incluso bastantes días después del desastre de Valmy, hasta que la evidencia de las circunstancias le impusieron el «pacifismo» $\left({ }^{3}\right)$. Como comenta Chaumié, "Aranda - son sus palabras textuales - a pesar del barniz filosófico que había podido coger en París en sus relaciones con los enciclopedistas, permaneció esencialmente español y muy desconfíado de toda corriente de pensamiento proveniente del otro lado de los Pirineos, ya viniera de los agentes revolucionarios, o de los emigrados realistas» $\left({ }^{4}\right)$.

\section{Guerra contra la Revolución}

Para conocer los preliminares de la actitud de Aranda contra la República francesa, hay que remontarse al célebre Consejo de Estado del 24 de agosto de 1792, convocado por el conde de Aranda cuando tuvo conocimiento de la insurrección popular del 10 de agosto en París, con el asalto y matanzas de palacio, en que el rey fue despojado de su autoridad, - convocándose una Convención Nacional. En él planteó la cuestión de si había llegado la hora de intervenir. El Memorial consta de diez proposiciones, que ponen al vivo la manera de ser de Aranda, y que no dejan cabo suelto, planteando los pros y los contras de una actitud a tomar contra la Revolución Francesa, con el fin de «reponer a Luis XVI en los justos derechos de su soberania» $\left({ }^{5}\right)$.

Por una parte pregunta, si «deberíamos unir nuestras armas' con los soberanos europeos (prop. 2. ${ }^{a}$ ), pero en seguida presenta el reverso de la medalla: « ¿Sería de temer por ventura que la Inglaterra, que hasta ahora se mantiene neutral, se aprovechase de nuestra guerra contra Francia, y que, viéndonos ocupados en este grave empeño, acometiese alguna de las posesiones de Ultramar?» (prop. 3. ${ }^{a}$ ). Idea ésta que la llevaba muy metida Aranda, siendo una de las causas que más le retenían en la neutralidad $\left(^{6}\right)$. Caso de que

(3) J.A. Ferrer Benimeli, El Conde de Aranda y el frente aragonés en la guerra contra la Convención (1793-1795), Zaragoza, Universidad, 1965, pp. 96-128.

(4) J. Chaumié, Les relations diplomatiques entre l'Espagne, et la France de Varennes à la morte de Louis XVI, Bordeaux, 1957, v. 95.

(5) A. Muriel, Historia de Carlos IV, Madrid, B.A.E., 1958 trae textualmente nueve de las proposiciones que hemos nodido comprobar en el Archivo Histórico Nacional (A.H.N.), Estałı 2863-12 lo que prueba la rectitud y objetividad de los documentos aportados por Muriel.

(6) Son muchos los historiadores que coinciden en la misma visión respecto a las "apetencias" inglesas, y que luego la Historia se encargó de confirmar, dando una vez más la razón a Aranda. Sobre Aranda y América cfr. J.A. Ferrer Benimeli, América en el pensamiento 
se restableciese el gobierno francés, «¿no sería más conveniente entregarnos a esta esperanza, y ganarnos la voluntad de un pueblo que fuese en lo sucesivo nuestro apoyo» (prop. 4. ${ }^{\mathrm{a}}$ ).

Aranda siempre prefirió la amistad del pueblo francés, al inglés, - pues se ajustaba mejor a nuestra manera de ser, y la historia lo confirmaba; le parecía que, mientras España tuviera un buen aliado, no habría que temer a Inglaterra. Pero, por otra parte - se preguntaba el conde -, ¿no sería indecorosa e inexcusable la apatía de España, «cuando las principales potencias de Europa hacen, aunque por otros motivos», lo que no practicarían por ayudar a un monarca en desgracia? (prop. 5. ${ }^{\mathrm{a}}$ ). Todavía - cabía una solución intermedia, presentarnos armados sí, pero ofreciendo nuestra mediación (prop. 6. ${ }^{\mathrm{a}}$ ). Caso de que se resolviera el último extremo de tomar las armas, sería conveniente comunicarlo a las Potencias europeas, para que vieran que «la inacción que nos echaban en cara provenía únicamente de no haberse presentado todavía la ocasión favorable para declararnos» (prop. 7. ${ }^{a}$ ).

Una de las ideas más debatidas por algunos historiadores es el cuidado que muestra Aranda, en su proposición 9.", que una vez resuelta la guerra, se guardara la decisión en secreto, para que los preparativos no se vieran dificultados y las tropas pudieran estar en la frontera antes de publicarse la declaración, pues «¿quién sabe - decía - lo que puede sobrevenir de un instante a otro, visto los excescs cometidos últimamente? Aparentando con estudio que nuestros armamentos no son otra cosa que medidas de prudencia, se contendrán quizá aquellos espíritus, y no romperían los primeros».

No pasarían muchos meses antes de que se viera cuánta razón encerraban estas palabras de Aranda. Las reflexiones finales giraban alrededor de una visión tenebrosa del futuro de Luis XVI ( «iA dónde iría a parar la imaginación, de lo que pudiere acontecerle?), y están dictadas por el temor de «no precipitar una catástrofe a las Reales Personas», donde se vislumbra una vez más ese don profético de Casandra - como acertadamente le llama $R$. Olaechea - de que estuvo dotado Aranda $\left({ }^{7}\right)$. Dueño de un agudo olfato político, barruntaba ya el final de los reyes franceses, como barruntó la catástrofe de

politico del Conde de Aranda, Actas del Congresso de Historia de los Estados Unidos, Universidad Hispanoamericana de La Rábia (Huelva), 5.9 julio 1976., Madrid, Servicio de publicaciones del Ministerio de Educación y Ciencia, 1978, pp. 39-49.

(7) R. Olaechea, «Notas en torno al ex-jesuita G. Iriarte, hermano del Conde de Aranda", Archivum Historicum S. I. (Roma), 33 (1964), 157-234 
la América española, así como la parte que Inglaterra tendría en ello.

En el Consejo se decidió la entrada de España en la guerra. De todas formas, también se acordó en la misma sesión que las relaciones diplomáticas con Francia no serían rotas. Arteche, comentando las proposiciones de Aranda, demuestra tanto su desconocimiento de la política del conde en este asunto, como son exaltadas sus críticas, y no se queda corto en su ataque. $\mathrm{Y}$ es que, en realidad, son pocos los que han calado la verdadera actitud de Aranda $\left(^{8}\right)$. Los historiadores, al tratar de razonar la postura del conde, han caído fácilmente en los clásicos tópicos forjados alrededor del «masón y volteriano» Aranda, siendo así que, para comprender los móviles que determinaron su política - durante el ministerio de 1792 no hay que pretenderlos explicar, ni mucho menos, - nos dice Chaumié - por una adhesión a un partido político francés, ya sea éste monárquico, jacobino o aristocrático $\left(^{(}\right)$.

Basta ver como actuó con ocasión del - tan criticado Consejo de Agosto del 92. Estuvo esperando a que los imperiales austriacos desencadenaran la batalla, para él echar sus cartas. Cuando el 25 de julio de 1792, Lacy le advirtió de la marcha, hacia las fronteras del Este, de tropas francesas en guarnición en el Rosellón, entonces fue - y no a raíz de los sucesos del 10 de Agosto - cuando Aranda se decidió a entrar en campaña. El 7 de agosto, es decir tres días antes de los sucesos de París, escribía a Lacy una interesante carta, en la que se descubre su verdadero pensamiento. Comienza por justificar la confianza muy particular que tiene en Lacy, el talento militar, el valor personal, y el puesto que ocupa, hacen del Gobernador de Cataluña la persona más al corriente de lo que pasa en el principado y fronteras de Francia. Aranda prevé la entrada en París de los ejércitos austriacos y prusianos, y la derrota de los «rebeldes» de la Asamblea, juzgando que el momento oportuno ha llegado para España: «Parece que sería l'à propos de presentarse también por nuestro lado armado, así para dar sujección a los rebeldes...., para ofrecernos a unos y a otros de mediadores, para un ajuste racional y reparación de la descuadernada monarquía» $\left({ }^{10}\right)$. La carta termina con

(8) J. Gomez de Arteche, «Historia General de España, Reinado de Carlos IV", en Historia General de España, dirigida por Cánovas del Castillo, Madrid, 1890, t. I, pp. 106-109.

(9) Chaumié, ob. cit., p. 95.

(10) A.H.N., Estado 3944. 
instrucciones de carácter puramente militar, sobre las medidas a tomar en el caso de una invasión del Rosellón por los ejércitos españoles.

Sería un grave error psicológico - nos dice Chaumié confundir el gesto del ministro español, esperando para entrar en el conflicto, a que Francia fuera atacada en todas sus fronteras. No hubo en ello miras bastardas, ni móvil alguno interesado intervino en su decisión. España no solamente rehusaba anexionar un centímetro del suelo francés, sino que se oponía a todo crecimiento de las Potencias coaligadas con detrimento de Francia. Aranda, sí quería aumentar el prestigio de España, y contribuir a la caída de la Revolución, pero sobre todo lo que pretendía era servir de árbitro entre los beligerantes, y proteger los intereses de la monarquía francesa contra la rapacidad de Austria y Prusia.

Esta carta del 7 de agosto de 1792, muestra claramente cómo los contemporáneos, y después de ellos historiadores como Gómez Arteche, Sorel, Seco Serrano o Tratchevsky, se engañaron sobre la decantada "simpatía de Aranda por la Revolución francesa» $\left.{ }^{11}\right)$.

El 24 de agosto fue decretada, pues, la aceptación de la guerra (declarada antes por la Convención), por decisión del Consejo, si bien Aranda no había esperado tal decisión, adelantándose a ella y poniendo al corriente de las nuevas disposiciones a Lacy, comandante en jefe del ejército de Cataluña, Aranda descubrió también sus intenciones a algunas Potencias, con el fin de poder combinar su acción militar. Los primeros en ser prevenidos fueron los Borbones de Nápoles y Cerdeña, por cartas del 21 y 28 de agosto $\left({ }^{12}\right)$. Posteriormente, el 31 de agosto envió un despacho a Campo, ministro de España en Londres, proponiéndole no la invasión de Francia, sino que todos los países se unieran, para impedir «la presencia del pabellón francés en los mares», y hacer una especie de bloqueo que matara el comercio y la industria franceses $\left({ }^{13}\right)$. Finalmente, el 4 de septiembre enviaba Aranda, desde el Paular,

(11) Gomez Arteche, ob. cit., t. I, p. 104; A. Sorel, «La Diplomatie Française en l'Espagne de 1792 à 1796», Revue Historique, XI (1879) 305; C. Seco Serrano, Godoy: el hombre y el politico. Estudio preliminar a las Memorias del Príncipe de la Paz, Madrid, B.A.E., 1956, pp. XXI-XXII; A. Tratchevsky, "L'Espagne à l'époque de la Revolution Française», Revolution Historique, XXXI (1885), pp. 35-36.

(12) A.H.N., Estado 3942-43 y 2863-12 y 13.

(13) A.H.N., Estado 2942-2. 
una Circular a los ministros españoles en las Cortes de Viena, Berlín, Turín, San Petersburgo y Estocolmo, previniéndoles que «S. M. había resuelto acercar tropas a las fronteras de Francia, que estarían prontas a salir a campaña en formal ejército, si las otras potencias se empeñasen, y obrasen también, por su parte, con la actividad correspondiente al objeto, en los términos que creyesen más convenientes» ${ }^{\left({ }^{14}\right)}$.

\section{Primer plan de campaña de Aranda}

Muriel, comentando esta circular de Aranda a las Potencias Europeas, tacha de arrojada la resolución de entrar en guerra contra un pueblo dominado entonces por las pasiones más violentas, «sin haber tomado de antemano ninguna medida, para emprenderla con ventaja, y sin haber tratado antes con las Potencias beligerantes, sobre el modo de entenderse para el buen éxito de las operaciones militares» $\left({ }^{15}\right)$. Está en lo cierto en lo de «arrojada resolución», pues el mismo conde de Aranda, reflexionando en tiempos posteriores sobre su propia resolución, la llama «un acaloramiento»; pero respecto a que se había tomado ninguna medida de antemano, yerra el ilustre historiador, tachado de ser acérrimo defensor del Conde. Con todo, aun en aquel instante de fervorosa exaltación, el ministro español no perdía de vista los peligros que podían amenazar al reino, y con gran sensatez cuidó de dar a los aprestos militares la apariencia no de actos hcstiles, sino de «medidas precaucionales», expresión favorita de que se sirve en el informe que hizo al Rey Carlos IV, en San Ildefonso, el 7 de septiembre, «sobre el modo de acometer a los franceses».

Este es el primer plan de campaña contra la Francia revolucionaria de los jacobinos y volterianos, plasmado - no sin su dejo de ironía histórica - por aquel ministro al que los contemporáneos, y no poca gente después, acusaron sin razón, de ser partidario de la Revolución francesa.

El plan ocupa cinco folios escritcs por ambos lados. Tras un corto preámbulo, en que se justifica ante el rey del dicho informe, nos dirá cual es la motivación de la guerra: «Tratar de que España, como una de tantas Potencias, cibligue a Francia a someterse a su legítimo soberano, como debe, sin mezclarse en más que en sujetar a los espíritus revoltosos, que causan

(14) A.H.N., Estado 2863-21. Muriel, ob. cit., t. I, pp. 276-279 la copia literalmente.

(15) Muriel, ob. cit., t. I, pp. 278-279. 
el desorden que es notorio; y como no es adquisición de plazas ni provincias lo que interesa España para sí, parece que sus operaciones han de dirigirse al fin expresado» $\left({ }^{16}\right)$.

Según esto, lo mejor para el conde sería «una acometida activa y rápida, pero con fuerzas respetables, ya por decoro propio, ya por no aventurar el éxito, ya también por abreviar la consecución y ya por dispensarse de los gastos considerables que trae consigo la guerra, cuando es larga». A continuación aconseja que de las entradas (Cataluña y Navarra-Guipúzcoa), que "pueden hacerse en Francia, con el grueso de un ejército", la invasión por Cataluña sería más fácil», por una serie de causas que analiza pormenorizadamente, con el fin de apretar más a la Asamblea francesa.

De todas formas, contaba con que los dos ejércitos - el de Cataluña y el de Navarra-Guipúzcoa - podrían reunirse «en un mismo punto, hacia la parte septentrional de Bayona y todo el Garona». Aprovecha la ocasión para entrar en varias consideraciones militares, donde podemos ver la vocación castrense de Aranda, que trata desde las economías, en tiempo de guerra, hasta el modo de evitar la vanidad en los jefes de la tropa.

Ante la dificultad de formar dos ejércitos poderosos, los dos suficientes para la ofensiva que pudiera llevarlos a reunirse en la región central del Pirineo francés (sin desatender, por eso, el darse la mano con los Piamonteses), y sobre el no ser posible organizarlos en el tiempo perentorio que exigían las circunstancias del momento, insistirá en la conveniencia de disimular lo más posible «el verdadero fin que se lleva», dándole el carácer «precaucional».

$\mathrm{Y}$ ya hasta el final, y de un modo reiterativo - excepto en el apartado sobre los equipajes de los trenes y de la artillería -, se mueve alrededor de la misma idea, es a saber: «de disimular mejor nuestros fines», para lo que sería «conveniente no publicar los oficiales generales, ni el Estado Mayor del ejército, hasta el tiempo preciso de su concurrencia para reunirle», pues, «a la manera de los teatros, no se había de descubrir la comparsa hasta levantar el telón».

Aranda concluye su plan diciendo que faltaba por disponer lo principal: el dinero. Los gastos iban a ser considerables y por ello recomendaba al rey que diera órdenes a los departamentos de Guerra y Hacienda para que se entendieran entre sí sobre el particular.

(16) A.H.N., Estado 2863-12. 
A los pocos días, el 16 de septiembre, volvía Aranda sobre el tema, entregando al Rey un despacho en el que explicaba y completaba las disposiciones necesarias para seguir el anterior plan de campaña. Recibidas las noticias, "que yo había cometido al Capitán General de Cataluña privadamente, desde el 7 de agosto, para que supiéramos, con probabilidad, si por aquella parte cabría el ingresso en Francia, sin obstáculos insuperables», y habiéndose explicado el conde de Lacy, «con la proporción que apetecíamos» - leemos en el memorial del 16 de septiembre -, «se ha resuelto ya V. M. a preferir la parte de Cataluña más bien que tomar las de Navarra o Guipúzcoa» $\left({ }^{17}\right)$. A continuación indica cómo el Ministro de la Guerra estaba informado, y que había «insinuado al de Hacienda sus reales intenciones, para las prontas asistencias que se ofrecían». Insiste sobre todo en el aspecto económico, pues «la parte militar es más fácil de aprontar, pero los medios del real erario necesitaban de providencia activa, para dar complemento al uso de las armas». Una vez más, Aranda da muestras de su espíritu detallista, que intenta salir al paso y subsanar con tiempo las menores dificultades que pudieran impedir el éxito de la empresa.

Esta vez su atención va dirigida al acopio de trigo, cebada y paja - necesarios para «el tiro y sus carruajes, las acémilas de munición y provisión -, artículos que no se preparan como los batallones y escuadrones, y que además exigen «un considerable gasto extraordinario». Pero la dificultad mayor no era ésta, pues «si fuese una guerra defensiva de la casa propia, todo es más fácil a pie firme, y el mismo país concurre como hormigas a suplir las dichas necesidades; pero se trata - decís - de salir fuera, y en tal caso son diferentes las medidas, pues todo se ha de llevar consigo; y como es de primera necesidad, y de gran bulto para moverse, no admite dilación en sus disposiciones».

Además, debía contarse con que en el país vecino no se había de hallar el menor recurso. Tras entrar en una serie de detalles y cálculos, relativos al aprovisionamiento de forrajes para las caballerías, concluía: «Añádansele los víveres, municiones de guerra,.... y este conjunto convencerá, por el sólo acopio de forraje, de las urgencias de que el ramo de Hacienda no puede rescindir, ni atrasar».

A esto va dirigido el memorial, a urgir a la Hacienda su apoyo, para poder llevar a efecto el plan de campaña. Acaba con unas palabras que, a la par que ponen de manifiesto su

(17) A.H.N., Estado 2863-21. 
conciencia profesional, muestran un conocimiento psicológico del momento, digno de resaltar:

«Mi profesión militar - escribe - me impone la obligación de hacer presentes a V.M. las observaciones, que no siguiéndola, me serían excusables. En el día, sus reales órdenes para Hacienda convienen positivas, y no indicadas; porque el mismo Ministerio así las necesita, a la verdad, para obrar según ellas. Son dos extremos la insinuación y la resolución. Si la primera se toma con templanza, es disculpable, más no la segunda en moderar su cumplimiento. Por esa diferencia conviene que la real voluntad se explique en el agrado que se hubiera de dar a sus preceptos; y sus ministros puedan conducirse arregladamente en su desempeño; de otra forma, los unos por los otros se suelen enfriar, observándose recíprocamente el movimiento, y esto sucede más frecuentemente. que lo opuesto: de avivarse porque el otro se acalore».

A modo de complemento del plan de campaña anterior, - «sucinta idea de las disposiciones militares» como lo llama su autor, tenemos que añadir las diversas medidas adoptadas para llevarlo a cabo. La correspondencia entre Aranda y Lacy, en agosto y septiembre de 1792, está llena de cambios de impresiones sobre los preparativos de la guerra próxima. El punto más importante era el acondicionamiento de carreteras o vías de acceso hacia los Pirineos, sobre todo en la parte de Cataluña, pues fuera de dos carreteras mal conservadas, los únicos caminos entonces existentes eran antiguas vías romanas o senderos de cabra, a través de la montaña. Pero no bastaba con preparar los caminos para las tropas; era preciso disponer de fuerzas militares suficientes. Consecuencia de la decisión de atacar por Cataluña, "al no tener ejércitos competentes, para entrar por todas partes», fue el ir aumentando el número de tropas en Cataluña. A Guipúzcoa y Navarra se dejó únicamente lo preciso para mantenerse sobre la defensiva. Aragón quedó todavía peor parado, "pues no se pensó en reforzar(le), y se dejó sólo su guarnición, así por considerar difícil que los franceses penetrasen por aquella frontera, en la que no hay caminos para conducir artillería, como por haber escrito D. Félix O'Reilly le bastaba la tropa que había, para defender con ellas y los Paisanos las entradas de aquel Reino, y necesitase los cuerpos en Cataluña». Pero la obligación de obrar en secreto volvía delicadas todas estas tareas, que no podían ser conducidas tan rápidamente como si hubieran sido llevadas abiertamente $\left({ }^{18}\right)$.

(18) Ferrer Benimeli, ob. cit. El Conde de Aranda y el frente...., pp. 298-299. 
Fruto de esta cautela fue el despiste del mismo Bourgoing, plenipotenciario francés en Madrid, quien no sospechó durante el verano de 1792 las intenciones belicosas de España, a pesar de que Arteche opine y afirme categóricamente lo contrario ${ }^{\left({ }^{19}\right)}$. Durante el transcurso de septiembre, Bourgoing advertía a Lebrún que los preparativos militares de España se acentuaban, afirmando que no comportaban ningún carácter alarmante, sino que eran esencialmente defensivos $\left({ }^{20}\right)$.

Todo este compás de espera tuvo un fin inesperado, pues el 21 de septiembre, el cañón de Valmy redujo a cenizas los sueños eufóricos de los contrarrevolucionarios, cambiando la faz del mundo, según expresión de Goehte. No obstante, el deseo belicista de Aranda era tal, que el 16 de octubre todavía escribía:

\begin{abstract}
"Al fin de mes se sabrá a qué atenerse, y obraremos según las circunstancias. Mientras esperemos, tengámonos en observación. Si los alemanes entran en París, y entrase el pavor en los fanáticos gallos, más que fuese sobre nieves habíamos de procurar aumentar la confusión. Si lo contrario, esperar el invierno» (21).
\end{abstract}

\title{
Neutralidad armada
}

Pero a pesar del optimismo bélico anterior, ya el 24 de octubre, tanto Lacy como Aranda llegaron al acuerdo de que, «en el estado actual de las cosas y verificada la retirada de los alemanes, sólo debemos pensar en formar un Cordón defensivo....» $\left({ }^{22}\right)$, debido sobre todo a que el temor del dinamismo de los ejércitos revolucionarios les arrastrara a tomar la ofensiva en el Rosellón. Las causas que actuaron en esta decisión fueron, por una parte, el pésimo estado de los asuntos financieros, y la escasa preparación para la lucha; pero sobre todo venía impuesta por el cambio de situación que supuso el triunfo francés al derrotar al ejército prusiano. En último término, también pesaba la posición delicada del Rey prisionero, que no convenía agravar. Razones todas ellas, que si se quiere - como afirma Fervel -, ocultan las pruebas de impotencia de España pero no la falta de entereza y patriotismo

(19) Gomez Arteche, ob. cit., t. I, pp. 113-114.

(20) Archives Diplomatiques. París. Espagne, 633.

(21) A.H.N., Estado 3944. El subrayado en nuestro para resaltar la expresión que dedica el «volteriano» Aranda a sus amigos (?) los «fanáticos gallos».

(22) A.H.N., Estado 3944. 
por parte de Aranda, como parece querer indicar Seco Serrano, para quien la guerra no llegó a declararse, pues «indudablemente luchaban en el interior del ministro dos fuerzas contrapuestas. Seguía siendo fiel al rey, pero había demasiados puntos de contacto entre su propio ideario y el de la Revolución» $\left({ }^{23}\right)$. En un intento de explicación aduce tres juicios, uno de Geoffroy de Grandmaison, otro de Pereyra, y otro de Gómez Arteche, que nos ofrecen los tópicos tan aireados de la amistad de Aranda con los filósofos, de su frialdad religiosa por la parte que tomó en la expulsión de los jesuítas, y el haber sido el introductor de la masonería en España $\left({ }^{24}\right)$.

Para contrarrestar tales juicios, que ya hemos visto más arriba carecen de fundamentación histórica, bastaría con reproducir la contestación que dio el "amigo» de lcs «fanáticos gallos» a Bourgoing, cuando éste llegó a emplear cierto tono de amenaza, al hablar de «los millones de habitantes, y de los cientos de miles de bayonetas que la Francia contaba, y de la posibilidad de que su población y su fuerza la hicieran no poder contenerse dentro de sus límites». Tanto molestó a Aranda esta fanfarronada que, en uno de aquellos arranques de su impetuoso genio, llegó a decirle que, si tal caso sobreviniera,

«él mismo aunque era primer oficial general del Ejército de $s:$ Soberano, le pediría al Rey no el mando, sino un tambor para reclutar gente que le siguiera, y que entonces se vería cómo atropellaban los hogares patrios. los cuerpos y los corazones de una nación valiente, bastante numerosa para hacer frente, en su suelo a la más atrevida y poblada" (25).

La situación se imponía al conde aragonés, situación que fácilmente se simplifica, cuando en realidad jugaban factores tan variados como delicados. Un aspecto que habitualmente se suele silenciar, pero que, el 17 de febrero de 1793, puso sobre el tapete Aranda, en sus "Observaciones sobre si convendría a la España el declararse contra la Francia o más bien mante-

(23) Seco Serrano, ob. cit., pp. XXI-XXII.

(24) Sobre la total base histórica de dichos tópicos cfr. Olaechea y Ferrer Benimeli, ob. cit., t. I, pp. 88-109, t. II, pp. 7-27; Ferrer Benimeli, El Conde de Aranda y su defensa de España. Refutación del "Viaje de Fígaro a España», Zaragoza, Facultad de Filosofía y Letras, 1972; "La Masonería española en el siglo XVIII. ¿Fundó el Conde de Aranda el Gran Oriente de Esnaña?», Historia 16 (Madrid), Extra IV: La Masonería, (noviembre 1977). 45-46: "Voltaire, España y Aranda", - Historia 16, n. 29 (septiembre 1978) 33-45.

(25) M. Lafuente, Historia General de España, Barcelona, Montaner y Simón, 1889, t. XV, p. 119. 
nerse neutral armada» $\left({ }^{26}\right)$, es el del peligro de las sublevaciones interiores. $\mathrm{Y}$ prueba de que dicho temor no era una argucia infundada del Conde, tenemos la carta de Sandoz, del 22 de octubre de 1792 que dice así:

«La menor subida de impuestos provocaría un levantamiento en varias provincias, especialmente en Cataluña y Galicia. Vizcaya, Aragón y Cataluña, considerarían a los franceses - como lo han hecho los saboyanos - no como enemigos, sino como salvadores. Y no sería de extrañar que toda la península no pusiera en pie de guerra, ni siquiera 10.000 hombres, según las pretensiones de la corte».

Todo esto - añadirá Dozy - pesaba gravemente tanto en Aranda como en el Consejo de Estado, al que el ministro había propuesto qué es lo que podía y debía hacerse $\left({ }^{27}\right)$.

\section{Caida del conde de Aranda}

Pocos días después, el 15 de noviembre, Aranda se veía obligado a cesar en el desempeño interino del Ministerio de Estado (28). Al enumerar las causas que ocasionaron su caída habría que fijarse, por una parte, en la hostilidad de un extenso sector de la opinión pública, y por otra, en la escasa simpatia que inspiraba el conde a la reina María Luisa y a Godoy, su favorito; hostilidad y recelo basados no tanto en su pretendido "afrancesamiento», cuanto en su política del "partido aragonés» $\left({ }^{29}\right)$, y en su posición neutralista de última hora, con relación a negarse a un rompimiento con Francia. Y es que Aranda sabía unir su amor a la monarquía y a España, con una visión realista de su situación militar, por lo que se resistía a creer

(26) A.H.N., Estado 2849-6.

Si es cierto que la gran masa de la nación no tiene la menor idea de los derechos del hombre. y confunde el Estado con el trono y el soberano con la soberanía, no es menos cierto que hay pocas naciones en Europa en las que estos principios tienen tanta resonancia como aquí y que bastaría que las provincias sacudieran el yugo, para que las demás siguieran inmediatamente su ejemplo».

(27) R. Dozy, "Spanien gegenüber der französischen Revolution", Hist. Zeitsch. (München), IX )1893) 94.

(28) J.A. Ferrer Benimeli, El Conde de Aranda, primer Secretario de Estado en Suma de Estudios em homenaie al Dr. Canellas, Zaragoza, Facultad de Filosofía y Letras, 1969, pp. 355-378.

(29) R. Olaechea, El Conde de Aranda y el "Partido Aragonés», Zaragoza, Facultad de Filosofía y Letras, 1969. 
en una guerra afortunada con Francia de la que, en el mejor de los casos, no habría ningún provecho que sacar y sí que padecer. Tampoco perdía de vista la repercusión que podría tener en las provincias americanas, donde - como afirma Pérez de Guzmán apropiándose unas palabras del propio conde de Aranda - «nada se les oculta de lo que por aquí pasa; tienen libros que los instruyen de las nuevas máximas de libertad, y no faltarán propagandistas que irán a persuadirles si llega el caso» $\left({ }^{30}\right)$.

Precisamente esta actitud de Aranda, serena pero firme en el asunto de la guerra contra Francia, parece ser que fue la que influyó en su caída. En cualquier caso, como recoge Muriel, la separación de Aranda de la Secretaría de Estado no debió provenir de que hubiese dirigido los negocios de Estado con inconsideración o desacierto.

Sobre este particular, es interesante la lectura del Diario que Aranda escribió por estas fechas. Entre el 28 de febrero de 1792 , y el jueves 15 de noviembre del mismo año, en que fue destituído de su cargo de la Secretaría de Estado, hay unas páginas que revelan el estado de ánimo de Aranda, en un intento de encontrar unas motivaciones, que justificaran la medida que los Reyes iban a adoptar a los ocho meses y medio de su nombramiento. $\mathrm{Y}$ aquí cabe destacar nuevamente el influjo y confianza de que gozaba Godoy, quien todas las veces que Aranda había sido recibido por la Reina, "por sí o con el Rey», ni una había dejado «de estar presente Alcudia desde el principio al fin, callando unas vezes y hablando otras según el asunto». Esta presencia de Alcudia, al lado de los Reyes, es algo que repite Aranda en su Diario hasta la saciedad, casi de forma obsesiva. Pero quizá lo más llamativo es ese análisis que hace el conde de su propia actuación ante la Reina, temeroso de haber incurrido en alguna falta o incluso indelicadeza para con ella. Es una preocupación que figura con insistencia en el Diario de Aranda, y que se refleja no sólo en el empeño de dejar constancia de que siempre contó con ella, sino del agrado y satisfacción que las actuaciones de Aranda le producían. "Desde el principio tuve el cuidado respetuoso - escribe - de presentarme a la Reina.... para enterarla de lo que había que mereciese la atención, y S. M. se dio siempre por satisfecha». Unas líneas más abajo hace notar que, en los tres

(30) Perez Guzman, «El primer conato de rebelión, precursor de la Revolución en España», España Moderna, CCL (1909) 107. 
despachos que tenía por semana, jamás tocó especie que pudiese disgustar a la Reina $\left.{ }^{(31}\right)$.

Hay, no obstante, un párrafo en el que el anciano conde señala, con cierta amargura y decepción cómo, a pesar del excesivo trabajo a que se vio sometido, «nunca se había hablado, ni indicado» si se cansaba en el desempeño del cargo. Es más, ni siquiera le habían insinuado «el menor desagrado de su exactitud $: \mathrm{y}$ claridad», antes bien habían demostrado su confianza y satisfación. Reproche que alude directamente a los motivos que alegarían para su «alejamiento» de la Secretaría de Estado.

De todas formas, sí hay un episodio un tanto desconcertante, que recoge cuidadosamente Aranda en su Diario.

\begin{abstract}
"Llegó el mes de noviembre - escribe - en que había, el 4 día del Rey, y el 12 sus años; pedí a la Reina delante de Alcudia, y sin misterio, si se dignaría acordar a mi mujer las entradas regulares, para proporcionarle el ponerse a sus reales pies y besarle la mano. Quedó S.M. suspensa; le expuse que la Condesa era Dama de su nueva Orden, era Grande, mujer del Decano del Consejo de Estado y del que ejercía la primera secretaría del despacho, y de un Capitán General, cuya reunión de circunstancias era casi imposible que concurriesen jamás en ninguna otra persona; que a más seguía todos los sitios, y era la sola de sus circunstancias privada de ponerse a sus Reales Pies. Que las mujeres de capitanes de Corps, y coroneles de Guardias por eso sólo las tenían; como igualmente varias otras cuyos maridos estaban como retirados por haber sido anteriormente de los que se llaman Jefes de Palacio. No me respondió ni si, ni no, sino que vería. y no se explicó más. En la misma ocasión - prosigue Aranda - dije a S.M. que, en la noche del 4 , y de las diez en adelante, tendría mi mujer un baile de las señoras que hubiese en el sitio, y algunas como sus hermanas, y amigas, que vendrian de Madrid; y ambos rogábamos a S.M. que permitiese a las Camaristas (entre éstas figuraban la duquesa de Miranda, la duquesa de Sotomayor, la de Medinasidonia, la marquesa de Ariza y la duquesa de Arcos), que después de su servicio concurriesen a divertirse un poco. Yo lo creía muy corriente - confiesa Aranda -, pero la Reina no lo acordó» (32).
\end{abstract}

Después de esa detenida y humillante alusión a la inexplicable actitud de la Reina respecto a la condesa de Aranda, y de rechazo a su marido, el anciano conde, y como sirviendo de introducción - tal vez con una intención explicativa del

(31) cfr. nota 28.

(32) Ibidem. 
desenlace -, nos encontramos con esta frase: «la continuación de su real agrado, tanto en público cuanto en privado -, parecía igual»; frase que precede inmediatamente en el Diario al día 15 de noviembre, fecha ésta clave en la vida de Aranda, ya que se vio obligado a cesar en el desempeño interino del Ministerio de Estado, de una forma muy similar a como en el 28 de febrero lo tuvo que hacer Floridablanca.

A este propósito escribiría Godoy en sus infidedignas Memorias: «A un Ministro perplejo y tímido hasta el exceso (Floridablanca), le había sucedido un anciano, por el otro extremo, que de nada se alarmaba (Aranda). Uno y otro le causaron espanto al Rey - prosigue Godoy -, el primero por indeciso; el segundo por confíado. $\mathrm{Y}$ ambos fueron eliminados». En esta ocasión, Aranda fue sorprendido por la decisión que le exoneraba del Ministerio interino de Estado, para el que fue nombrado el Duque de la Alcudia, a fin de que lo desempeñase en propiedad. No obstante si bien parece que para Aranda fue totalmente inesperada esta decisión o, al menos, la fecha en que tuvo lugar, no se puede decir lo mismo de otros ni tampoco de la parte que en ella iba a tener la Reina, como se desprende de las siguientes palabras recogidas por Dozy: «La situación de Aranda es difícil. Se desea su destitución. La Reina cree llegado el momento para ejecutar sus planes, y dar paso a sus proyectos».

Ya que ni Godoy ni Muriel narran cómo sucedió la entrevista, en la que se comunicó al conde que prescindían de sus servicios, el único documento que hace referencia pormenorizada a ello es el Diario de Aranda. Nuevamente cabe resaltar la presencia del duque de la Alcudia en la entrevista, en la que fue precisamente la Reina la que mantuvo la iniciativa, al igual que en la separación de Floridablanca. Es ella la que le dió la noticia y llevó toda la conversación. Y la razón que adujo a María Luisa fue el cansancio que debía acusar el anciano conde con el trabajo que hacía, y que por ello querían conservarle para cosas mayores, y aliviarle de las molestias. El papel del Rey en esta ocasión se limitó a mostrar confianza y aprecio por el conde, «apoyándose sobre el hombro derecho de Aranda».

He aquí la descripción que hace el propio Aranda:

«El jueves 15 de noviembre, habiendo llegado las noticias de Francia, sin ser más tiempo para llevarlas yo, antes que el rey entrase en el despacho, las envié a lo acostumbrado.

Serían las 8 y media de la noche, que me enviaron a llamar; fuí inmediatamente por tener mi silla de manos siempre pronta, y creyendo buenamente, que sería por las 
novedades de Francia, que no dejaban de ser interesantes, entré, y empezaron sus Majestades por hablar de ellas, presente también el duque de Alcudia. Luego me dijo la Reina: Aranda, estarás muy cansado con la vida que haces; respondí: Señora, si yo acierto en cumplir con mi obligación a gusto de Vuestras Majestades, todo trabajo se hace soportable. La reina dijo: es que te queremos conservar para las cosas mayores, $y$ aliviarte de las molestias. Yo, apercibiéndome luego que algo habría, dije: Jesús, señores, de cualquiera forma que vuestras Majestades dispusieren estaré a sus pies, y los serviré lo mejor que pudiere; ya en este mundo no puedo tener otro objeto, pues mis carreras están hechas, y será en mí muy debido, que hasta el último aliento corresponda yo, no teniendo otra voluntad, que la que fuere de sus reales personas. Ambos a un tiempo me dijeron que así lo comprendían, y lo apreciaban; y el Rey, desde el principio de esta conversación, se había mantenido a mi lado apoyado, y como recostado sobre mi hombro derecho muy expresivo. Nada más me dijeron, sino que les excusase la mala obra de haberme llamado en aquella hora, y que podía retirarme. Yo me despedí con el respeto debido, y volví a mi casa, al despacho de las cartas de Francia y demás del curso ordinario.

Apenas salí yo de palacio enviaron a buscar al Secretario de Estado y de Marina, don Antonio Valdés; y le dijeron mi cesación en el Despacho de Estado, quedando con sus honores, y en la propiedad del Decanato del Consejo de Estado; nombrando sus Majestades, para mi hueco interino, al duque de Alcudia en propiedad, y en presencia del mismo. Preguntóles Valdés si yo estaba prevenido; le respondieron que a mitad, pues me habían llamado, y díchomelo, excepto quién fuese el sucesor, pero que viniese él mismo a decírmelo, de paso para volver a su casa, para expedir los decretos correspondientes.

A eso de las nueve y media vino Valdés. Lo recibí en mi Gabinete, y me comunicó de parte de los Reys lo que va referido, diciéndome que por la mañana temprano me pasaría su oficio, como así lo hizon (33).

El resto del Diario va detallando lo sucedido en los días que siguieron a sua exoneración: visitas a Palacio, entrega de papeles y correspondencia, padrinazgo de Aranda en la recepción del Toysón por parte de Alcudia, etc. En este sentido, Aranda no puede menos de manifestar su sentimiento, por la poca atención y delicadeza que tuvo Alcudia con él con motivo del padrinazgo, aunque ni siquiera en esta ocasión pierde Aranda esa rara serenidad - mezcla de resignación y acatamiento a los deseos reales - , que es la pauta dominante de todo el Diario, donde no se encuentra una sola nota discordante,

(53) Ibidem. 


\section{El Conde de Aranda}

tan características del temperamento y carácter del conde aragonés.

Una vez cumplidos todos los trámites del traslado de papeles a su sucesor, el 3 de diciembre se trasladó Aranda a su residencia de Madrid, a donde llegó la Corte dos días más tarde. A partir de entonces, el conde tuvo buen cuidado de seguir acudiendo a palacio con regularidad, y en las horas comunes de la Corte, capillas, etc., así como en asistir con exactitud a los consejos de Estado.

Las últimas palabras de Diario de Aranda nos muestran una faceta íntima del conde:

«Mi trato personal con las gentes - escribe - es el mismo de siempre. Mi mesa reducida, de 8 hasta 12 personas; y el Portero empozó por tener una lista de los que podrían venir a comer indiferentemente: esparciendo yo que me quedaba a vivir en privado por algunos días de descanso, para cortar con esa voz la afluencia de los anteriores concurrentes. Y habiéndolo conseguido así, por más de un mes, dije después al Portero, que deiase entrar a los vinientes, pues yo lo podría ir diciendo a alguno; y mi mesa se ha servido según los más o menos que hubiese, llegando algunas veces a 18, 20, y aun 24 personas» ( $\left.{ }^{34}\right)$.

\section{Decano del Consejo de Estado}

El cese en el Ministerio no le impidió a Aranda seguir de cerca la política española, como Decano que era del Consejo de Castilla. Y a pesar de su razonada oposición a entrar en guerra con Francia, su patriotismo y conocimientos militares le llevaron a redactar un segundo plan de campaña, el 27 de febrero de 1793, al que seguiría un tercero a primeros de abril, del mismo año, una vez iniciadas ya las hostilidades $\left({ }^{35}\right)$.

Sin embargo, el anciano conde de Aranda estaba íntimamente convencido de la conveniencia de la neutralidad armada de España, y creyéndose con más derecho que otros para juzgar del estado del reino, en una extensa representación, que dirigió al rey el 23 de febrero del 93, le expuso las ventajas que esa neutralidad reportaría para la paz interior, y para la seguridad de la América española $\left({ }^{36}\right)$.

(34) Ibidem.

(35) Cfr. estos planes de campaña del Conde de Aranda en Ferrer Benimeli, ob. cit., El Conde de Aranda y el frente...., pp. 121-135.

(36) A.H.N., Estado 2849-6. 


\title{
El pensamiento politico del Decano
}

La carta de presentación con que el antiguo diplomático, anciano general y dimitido político se dirigía a su rey - después del trágico fin de Luis XVI -, nos da una muestra de la sinceridad con que exponía la conveniencia de la neutralidad, que había propuesto y negociado durante las últimas semanas de su ministerio.

\begin{abstract}
«Habrá quien me iguale en el fiel apego a la soberana persona de V.M.; mas no quien me exceda - dice Aranda haciendo la apología de sus méritos-. Habrá quien me supere en el talento natural de mi carrera militar; pero la variedad de mis destinos, con trato de los acreditados generales que han merecido un distinguido concepto en el orbe, me han facilitado, más que a otros, muchas nociones, con que poder discernir los empeños. Habrá quien, en lo político, posea las mayores luces; pero como éstas, con las militares juntas, suelen producir juicios diferentes, de los que cada carrera por sí sola formaría; también esta unión de profesiones me facilita la discusión de las ideas que conducen a explayar los pensamientos».
\end{abstract}

Bajo dos aspectos - el militar y el político - están hechas las observaciones adjuntas a dicha carta, que suman un total de 16 folios manuscritos por ambas caras, más «dos mapas explicativos, relativos al plan de campaña en los Pirineos, caso de guerra contra Francia». Es decir, que, aunque defienda su punto de vista sobre la neutralidad armada, llevado de sus «buenos deseos, que no tienen otro objeto que el de las ventajas de la monarquía y gloria de V. M.», todavía a finales de febrero de 1793 - esto es antes de decidirse por la guerra -, escribió un informe de ocho folios, sobre las invasiones militares, caso de no adoptarse la neutralidad; informe que amplió, con 11 folios más, a primeros de abril, con el fin de ayudar al bosquejo de las operaciones. Una muestra más de la sinceridad de los servicios del Conde, siempre dispuesto a ayudar a su patria. la España de Carlos IV, y no la Francia revolucionaria, a la que deja bastante mal parada, para ser tan afín a su ideología, como algunos dicen.

Bajo el título de «Observaciones sobre si convendría a la España el declararse contra la Francia, o más bien mantenerse neutral armada», escribió Aranda este informe, «luego que se supo la violencia cometida en París, con el rey cristianísimo Luis XVI, por si se tratase de ello, y del partido que la España estaría en el caso de tomar en el Consejo de Estado; para poder discutir en él con más precisión las especies principales». Tras el preámbulo consabido, pasa a exponer proli- 


\section{El Conde de Aranda}

jamente los fundamentos y razones de su sistema. El más importante de todos gira alrededor de la política inglesa y americana que, según el Conde, creaba «diferentes circunstancias en España, cuyos intereses no son conformes con los de las demás potencias».

Pero dejando a un lado este aspecto americanista, admira la valentía del conde al afirmar, en las circunstancias en que escribía este Memorial, que «aunque la Francia llegase a quedar republicana, por su esencia tendría siempre más analogía con la España, que no la Inglaterra, mirando estos asuntos como de Estado a Estado por sus constituciones, carácter de naciones, e intereses respectivos a cada una» $\left({ }^{37}\right)$.

Si leemos este párrafo provistos de las antiparras deformadoras, con que habitualmente se juzga a Aranda, veremos en él al masón y al amigo de Voltaire, al enciclcpedista y al jacobino admirador de la «liberté, égalité et fraternité». Pero si dejamos a un lado los prejuicios y lugares comunes, habremos de admitir que no deja de asistirle la razón, cuando afirma que, mucho menos heriría el puntillo de honra de España

«el reconciliarse un día con la Francia rebelde, no suya, que lo que ella practicó con dominios propios poseídos de herencia, y por su sangre. Se le separaron las Provincias de Holanda en República; igualmente el reino de Portugal, en rebelión, y al fin pararon en ser reconocidos, no sólo independientes, sino en desplegar una soberanía al par de la de su dueño, y otros potentados. Otro igual eiemplar en nuestros días ha ocurrido con las colonias inglesas americanas, y su metrópoli. Ahora. pues. si años más o menos habría de suceder con la República francesa no vasalla de la Esnaña, lo que ésta no pudo evitar con los sobredichos súbditos suyos... parece aue la prudente razón de Estado llamaría la atención a conducirse de modo que, a no presentarse un golpe seguro, se contemporizasen los medios que mantuviesen a las dos naciones en un conocimiento recíproco de poderse considerar mutuamente, como más homogéneas a un sucesivo enlace de sus intereses» (38).

Son los intereses de España lo que le obliga a Aranda a discurrir así; no se trata de dilucidar un caso de honra, por medio de un torneo medieval, sino de evitar el suicido de España. Pues

"ciertamente que al presente-dirá Aranda-la España por su decoro, y por el mal ejemplo de la cavsa, ni pudiera.

(37) Ibidem.

(38) Ibidem. 
ni debiera ladearse a los franceses; y a no interponerse otras consideraciones de Potencia a Potencia, aún debiera ser la primera en avivar el desagravio; pero es de toda importancia el preferir un partido de menos malas resultas al Estado".

Este largo memorandum, cuyos máximos argumentos giran alrededor del tema americano, tiene todavía un aspecto que sirve para clarificar un poco el pensamiento político de Aranda. Por si quedaran dudas sobre la simpatía de Aranda hacia la Francia republicana, basta examinar la parte que el general Gómez Arteche llama «maquiavélica», e incluso poco digna de España, «demasiado leal y arrogante para entregarse a tales desquites" $\left({ }^{39}\right)$, juicio un tanto quijotesco, tratándose de hechos acaecidos en el siglo XVIII.

Según Aranda, manteniéndose en la neutralidad armada podría suceder que a los franceses les fuese bien o mal. En el primer caso, «no se habrían agriado con nosotros, y necesitando de su reposo, y de restablecer para lo sucesivo una buena correspondencia con alguno, fuera muy natural que, aun por máximas políticas bien pensadas, hallasen más conveniencia con la España....». Pero si «se les observase encaminarse a desgracias, entonces sí que la inacción armada tendría el campo más ventajoso, de desplegar su fuerza; y entregándose por su lado a oprimir a los franceses, ya conturbados de sus malos sucesos por otras partes, sería el golpe decisivo, sin males resultas, como vencedores».

\section{Aranda y el partido pacifista}

Desde antes de declararse la guerra, existía en Madrid un partido pacifista que no la aprobaba; partido "corto en número y recatado - según las Memorias de Godoy -, y compuesto especialmente de gente letrada, jóvenes abogados, profesores de ciencias y estudiantes, pero sin que les faltara el apoyo de personas notables entre las clases elevadas» $\left({ }^{40}\right)$. Este partido, llamado por unos de «la oposición» y por otros de «la paz», había aumentado considerablemente después de un año de guerra, a causa de los éxitos franceses en el Norte. Su órgano en el Consejo, «el astuto Aranda», creyó llegada la ocasión de

(39) Gomez Arteche, ob. cit., p. 120.

(40) Godoy, Memorias, Madrid, B.A.E., 1956, t. I, cap. XVIII, pp. 66 y ss. 
volver a tomar el asunto de la paz, y se esforzó una vez más en demostrar que esta guerra era tan injusta como impolítica ( $\left.{ }^{41}\right)$.

Una vez más, la actitud de Aranda ha sido interpretađà tendenciosamente, queriendo buscar en este partido de la paz, no las auténticas razones, tantas vezes expresadas por el ex-ministro, sino otras tan innobles como inconsistentes, al no estar basadas en otra argumentación que en los «lugares comunes» históricos, tan frecuentemente usados al relatar este período del XVIII. Se ha llegado a decir, que si se abogaba por la paz, «más que por terminar la lucha con la Francia revolucionaria, de cuyos excesos abominaban», era por la pasión «de ver cuanto antes, vencido por ellos, y rechazado por la corte, al presuntuoso y prepotente valido Godoy» $\left(^{42}\right)$. Como prueba no se aporta más que el testimonio del favorito, en sus Memorias $\left({ }^{43}\right)$. Aranda. mucho antes de que Alcudia fuera elevado al poder. ya había defendido tenazmente la idea de la paz en múltiples ocasiones, no existiendo entonces la tal «enemistad» aducida.

No mayor consistencia tiene el hecho de atribuir sus ideas conciliadoras para con la Francia iacobina a una pretendida consecuencia con «sus tan arraigadas aficiones a los iniciadores de la Revolución. aquellos filósofos sus amigos" (44). Esta vez el argumento se disfraza de tópico. uno de esos muchos que se van copiando con profunda fidelidad pero con cuya paternidad nadie quiere responsabilizarse en última instancia.

Aranda, pues. a pesar de su dimisión en la Secretaría de Estado. siguió en la brecha, asistiendo a los Consejos, en su calidad de Decano, y manteniendo en todos ellos su postura pacifista, y su oposición a la política del favorito Godoy. En todas estas ocasiones, Aranda se vio apoyado por sus "partidarios». Testigo de excepción de la política española en esas fechas fue el embaiador austríaco en Madrid, conde von Kageneck. quien en tndos sus despachos de entonces se ocupa del conde aragonés $\left(^{45}\right)$.

Precisamente en el informe del 10 de febrero de 1794, confiesa, el embajador que era demasiado cierto «que este conde, y su más bien numeroso partido, son de opinión opuesta al sis-

(41) J.N. Fervel. Campagnes de la Révolution Française dans les Pyrénées orientales, París, 1851, t. II, p. 15.

(42) Gomez Arteche, ob. cit., t. I. p. 295.

(43) Godoy, ob. cit., t. I, cap. XXI, pp. 82 y ss.

(44) Gomez Arteche, ob. cit., t. I, pp. 295-296.

(45) J.A. Ferrer Benimeli. "F.1 destierro del conde de Aranda (1794) según los despachos del embajador austríacon, Hispania (Madrid), XXX (1970) 69-146. 
tema de la guerra contra los franceses, y emplean todos sus esfuerzos en persuadir al rey, que esta guerra sea llevada sólo en forma defensiva en la futura campaña, cuestión en la que muchas circunstancias colaboran al apoyo de sus razonamientos $\left.{ }^{46}\right)$. Este velado reconocimiento de la existencia de una motivación razonada, en la actitud «defensiva» de Aranda, no carece de valor, sobre todo si se tiene en cuenta la fecha - 10 de febrero - en que está escrito el despacho de Kageneck. Y es tanto más meritcrio cuanto que dicho embajador, siguiendo las directrices de su Corte, deseaba y fomentaba ardientemente la guerra activa; lo cual ayuda a comprender, de rechazo, la postura realista, que aconsejaba una actitud prudente en un momento en que como reconoce el propio Kageneck, muchas circunstancias colaboraban en apoyo de los razonamientos de Aranda.

El propio embajador austriaco detalla cuáles eran estas circunstancias: «Las más ventajosas consisten en la constatación de que las Cortes aliadas contra Francia consiguieron en la última campaña tan pocas ventajas, a pesar de los más sangrientos encuentros, con lo que se querrá demostrar que los franceses podrían más bien envanecerse de las ventajas». Por otro lado, como sostenían en el mismo Consejo los partidarios del conde de Aranda, España, en el mejor de los casos, «no sacaría ninguna ventaja con la más afortunada guerra contra Francia, sino más bien Inglaterra, cuyo Estado inmediatamente obtendría la soberanía del mar con su engrandecimiento, y principalmente lo ejercería contra España». Finalmente, estaba el capítulo financeiro, «ya que las necesidades, para mantener esta guerra, agotarían al Estado español tanto en gente como en dinero» $\left.{ }^{47}\right)$. Esas razones, expuestas por Kageneck, coinciden con las que - según Muriel - presentó Aranda en el Consejo de Estado, en un escrito del 3 de marzo de 1794, a cuya sesión no pudo asistir por encontrarse indispuesto, y eri ol cual declaraba el conde "ser aquella guerra injusta, impolítica y ruinosa», tanto más si se tenía en cuenta el estado lamentable de la Hacienda, el pésimo equipamiento de las tropas españolas, y el hecho de que el entusiasmo inicial del pueblo hispano iba decayendo.

Una vez más, Aranda y su partido se enfrentaron con la política belicista y descabellada del ministro de Estado Godoy, y con los caprichos y los espejismos engañosos de la reina

(46) Haus-Hof und Staatsarchiv Wien. Staatskanzlei, Spanien, Correspondenz, 1794. Faszikel 157, fols. 126-131.

(47) Ibidem. 
M. Luisa. Este dualismo queda bien patente en los despachos del embajador austriaco Kageneck, quien constantemente alude a la resistencia del «incansable conde de Aranda y de sus partidarios».

\section{Polémica Aranda-Godoy}

El enfrentamiento de pareceres entre el favorito y el conde, llegó a una situación límite en el Consejo del 14 de marzo de 1794, en el que, tras la lectura de un nuevo Memorial de Aranda, abogando por la paz, intervino Godoy - cuyo desacu ardo con el anciano general aragonés era bien conocido de todos - para defender la postura contraria $\left(^{(48)}\right.$.

Lo que realmente sucedió en aquella sesión no ha podido comprobarse todavía del todo, pues las dos versiones, extraoficiales, que se han publicado sobre este punto, son tan dispares como sus propios autores: por un lado Muriel, que tuvo a la vista, y utilizó, el acta de dicha sesisón; y por otro, las Memorias de Godoy, fruto de las elucubraciones del Príncipe de la $\mathrm{Paz}$, en los últimos años de su vida, y que encierran esa finalidad autodefensiva y justificativa, que este género de escritos suele esconder, y que, en este caso, va enfocada especialmente contra Muriel y Pradt ${ }^{\left({ }^{49}\right)}$.

Una voz de la calle, o si se quiere un testimonio popular sobre esta borrascosa sesión del 14 de marzo, la encontramos en los Diarios de Jovellanos, el cual invirtiendo la cronología, $\mathrm{y}$ anotando las noticias conforme llegaban a su conocimiento, escribía el jueves 10 de abril de 1794: "Cuentan así la desgracia del conde de Aranda; que por estar indispuesto dirigió al Consejo de Estado un papel probando las funestas consecuencias de la guerra, el mal estado del ejército, la falta de gente y auxilios, la de recursos; que dijo que en este punto se engañaba al Rey; que era preciso descorrer el velo y presentar las cosas como eran en sí. Que este papel no se leyó, o no se leyó del todo. Que el conde asistió a otro Consejo; que confirmó de palabra esto mismo; que le respondió al duque de la Alcudia; que hubo entre los dos sus contrapuntos; que el de Aranda

(48) Ferrer Benimeli, ob. cit., El conde de Aranda y el frente...., pp. 218-224.

(49) Godoy, ob. cit., t. I, cap. XIV y XV, pp. 50 y ss. «Respuesta a las injurias que acerca de esta guerra ha escrito contra mí $M$. de Pradt»; y cap. XXI, pp. 82 y ss: "Grande impostura dada a luz por D. Andrés Muriel. Observaciones acerca de ella». 


\section{Revista de História das Ideias}

rompió diciendo que, pues conocía que su persona y sus servicios no le eran agradables, no le quedaba otro recurso que retirarse; que lo hizo así, quedando el Rey en el Consejo».

En cambio el 20 de marzo, jueves, contando antes lo que, en realidad, ocurrió más tarde, anotaba en su Diario el mismo Jovellanos:
«Llega el correo con dos tristes noticias: la muerte del Capitán General D. Antonio Ricardos...., y el destierro del conde de Aranda el 14 de Marzo. Había asistido al Consejo de Estado; al salir de la sesión, el duque de la Alcudia llamó al Gobernador de Aranjuez y le dió la Real Orden; a las cinco de la tarde salió el conde en un coche de colleras; acompañóle el Gobernador hasta Ocaña; y le entregó a un ayudante, con quien siguió adelante; dicen unos que va confinado a Jaén; otros que al castillo de la Alhambra; lo dirá el tiempo».

A continuación veremos lo que sucedió al anciano general, pero de la lectura de estas líneas de Jovellanos - una voz en la calle - se deduce que Aranda se había convertido en una persona no grata, y que su destierro estaba preparado de antemano por Godoy, para acabar de una forma drástica y radical con su engorrosa presencia.

En la versión que da el propio Godoy de este incidente, encontramos 17 páginas de sus Memorias dedicadas al discurso de contestación que el favorito - dice - dió al Memorial del conde $\left({ }^{50}\right)$. Pero es el caso que el acta de la referida sesión, que Muriel vió y copió, nada dice de este discurso de Godoy, sino que refiere, por el contrario, que "concluída la lectura, el duque de Alcudia se volvió inmediatamente hacia el Rey, y le dijo:

«Señor, este es un papel que merece castigo, y al autor de él como a otras varias personas, que forman sociedades, y adoptan ideas contrarias al servicio de V.M., lo cual es un escándalo. Es preciso tomar providencias rigurosas. A los que somos ministros de V.M. nos toca celar mucho estas cosas, y detener la propagación de las mas próximas que se van extendiendo».

El altercado entre el conde y el ministro, que siguió a estas palabras, fue de lo más violento, a juzgar por el testimonio de Muriel ( $\left.{ }^{51}\right)$, según el cual parece que ambos contendientes llegaron a expresiones y gestos amenazadores, no contenidos

(50) Godoy, ob. cit., t. I, cap. XIX, pp. 70 y ss.

(51) Véase la relación íntegra en Muriel, ob. cit., t. II, pp. 214 y ss. 
ni por la presencia del monarca. Altercado que se reprodujo con la desacertada intervención del conde de Campomanes, sobre los procedimientos militares que podían utilizarse para atender la futura campaña bélica.

El rey, ofendido del tono de despecho con que se expresó Aranda (cuyo orgullo y carácter, excesivamente franco y un tanto brusco, se puso violentamente de manifiesto, al ser herido su amor propio por Godoy), manifestó harto claramente su enojo, en términos que el Consejo comprendió bien la suerte que al conde de Aranda podía esperar. Acordóse que el desagradable incidente entre Aranda y Alcudia quedara reservado al Consejo. Resolvióse la continuación de la guerra, y una hora después de acabada la sesión se presentaron en casa del conde, el secretario del Consejo y el gobernador, conde de Casa-Trejo, con la orden del ministro de la Guerra, para que Aranda emprendiese la marcha, en un coche que se le puso a la puerta, en dirección a Jaén, punto al que, por lo pronto, se destinaba su residencia ${ }^{52}$ ).

Entre las versiones de Muriel y del duque de Alcudia, las dos tan apasionadas, tan opuestas, no es fácil fijar de un modo irrebatible la verdad de las frases, todas agresivas, que se dirigieron los protagonistas de aquella escena tan violenta y tan irrespetuosa, dada la presencia del rey. La de Muriel, sin embargo, ofrece caracteres que le dan gran autoridad, y entre ellos, el haber insertado las intervenciones de los consejeros y del Rey, como la de D. Jerónimo Caballero, quien dijo: "Convendría que lo que acababa de pasar quedase sepultado dentro del Consejo....»; o la de D. Antonio Valdés, quien fue de la opinión que, en punto de aliados, era preferible el más fuerte, y que por esta razón, siendo Inglaterra la potencia que tenía por mar superioridad sobre los demás sería bueno tenerla propicia. O la misma del Rey, quien, al pasar junto al conde, cuando salía del Consejo, le dijo: «Con mi padre fuiste terco y atrevido, pero no llegaste a insultarle en su Consejo». Intervenciones que no existen en la versión del favorito, donde sólo hallamos su largo y bien pensado soliloquio defensivo a posteriori.

La única alusión que hemos encontrado de tal escena, se la debemos al conde de Montarco, autor del acta del Consejo de 12 de junio de 1795, en la que, al tratar la causa del desterrado Aranda,

«expuso su Real Persona parte del suceso e insulto personal que le hizo en el Consejo de 14 de marzo de 1794,

(52) Ibidem. 
estando a su lado el causante, dando (puesto en pie y descomedido) una fuerte palmada sobre la mesa, a presencia de S.M., de todos los Sres. Ministros del despacho y otros vocales del Consejo....»( $\left.{ }^{53}\right)$.

Fervel, también tiene su versión, no exenta de interés, si tenemos en cuenta que fue publicada en 1851, es decir, unos años antes que la obra de Muriel viera la luz pública (1893-94), lo que hace probable que no pudiera estar influida por ésta. $\mathrm{Y}$ sin embargo, se aproxima bastante a la del abate. El historiador francés pone en boca de Aranda estas palabras:

"Nuestra deuda es enorme - añadió con calor - (se aseguraba que la campaña de 1793 había costado 225 millones); el entusiasmo de la nación es ficticio; es un fuego católico que se vai apagando. Una gran potencia del norte acaba de separarse de la coalición; entonces España ya no tendrá más que pedir milagros a su apóstol Santiago».

Le respondió - prosigue Fervel - un joven favorito de la Corte. Godoy balbuceó algunas banalidades sobre su insolencia, la impiedad del gobierno francés, sobre su «cruzada de ateísmo». En el fondo, estos argumentos lastimosos dejaban entrever la esperanza del desmembramiento que Aranda acababa de evocar, como una amenaza. Pero el primogénito de los Borbones reinantes no podía, ciertamente, abandonar tan prontamente su parte, desertando de los primeros la causa de los reyes, que conservaba todavía tantas oportunidades. El partido de la guerra - concluye Fervel - le arrastró, pues, todavía; «y un destierro a provincias pagó lo que el monarca llamaba la insolencia de su antiguo ministro" $\left({ }^{54}\right)$.

Por su parte, el embajador austriaco Kageneck comunicaba así el alejamiento de la Corte del Decano del Consejo:

«Después de la lectura del Memorial, que Aranda envió al Consejo el día 11, al duque de Alcunia le fue posible serenar tanto al Monarca, irritado por estas inconveniencias, como al Consejo, que manifestaba unánimemente su disconformidad, y fue acordado dejar de lado la cosa. Pero el conde se presentó en la sesión del 14, para repetir oralmente lo que había escrito antes, - acompañándolo con los más amargos reproches. Entre otros: que hubiera sido de esperar que a las ideas de un hombre, que había asistido a tantas campañas, y que durante su vida había estado

(53) A.H.N., Estado 926. Sobre su arresto en la Alhambra (1794-95) cfr. A.H.N., Estado 2822; M. Tobaja Lopez, "Destierro del conde de Aranda», Reales Sitios (Madrid), n. 56 (julio 1978) $51-56$

(54) Fervel, ob. cit., t. II, p. 15. 
dedicado al aprendizaje de la estrategia militar y a los más importantes negocios del Estado, y que había dado pruebas de su competencia y su zelo en el servicio, en cuya ocupación había encanecido; que a la opinión de un hombre, que desde su nacimiento estuvo adornado con ios más deseables títulos, a modo de galardón, y con otros muchos no despreciables, - hubiese sido de esperar - que se le hubiese concedido la preferencia ante aquél (Godoy) a quien falta todo esto. Con esto se colmó la medida. El Consejo se levantó; el Rey mandó permanecer al Secretario de Estado en la sala del Consejo, mientras los restantes consejeros se retiraron. Los principales acompañaron a Su Majestad hasta la Reina, que estaba en cama por su reciente parto, y la separación del Conde de Aranda fue decretada y puesta en práctica» (55).

\section{Destierro de Aranda}

Así pues, la consecuencia inmediata de las intervenciones del conde, en el memorable Consejo de marzo, fue su destierro. Pero hacía falta encontrar una motivación que justificara tal decisión. En opinión - bastante desacertada - de algunos historiadores, ésta se basó en el altercado reproducido por Muriel:

«Godoy.... echó en cara a su antagonista su vinculación a la masonería. A esto apuntaba su alusión a las 'sociedades e ideas contrarias al servicio de Su Majestad'. Ahora bien: a Carlos IV no podía caberle duda alguna acerca de la realidad del hecho. En sus tiempos de príncipe de Asturias, cuando la 'cabala' casi le tenía en sus manos, él mismo había sido invitado a ingresar en la secta. Y las relaciones entre la secta y la Revolución eran harto patentes. La tozudez de Aranda en su parcialidad pacifista, no dejaba de ser una prueba de ello. Godoy no necesitó más argumentos para provocar el destierro del conde: en todo caso, la irrespetuosa aspereza de éste, al contestar a su atacante, acabó de decidir la voluntad del monarca» (56).

Esta es la cita, no de lo que dice Muriel, sino de la interpretación tendenciosa y en cualquier caso falsa, que algunos historiadores hacen de las palabras del abate Muriel, quien solamente alude a sociedades o facciones - que ese es el sentido y significado que, en aquella época, tenía la palabra "cábala», y no la de sociedad secreta, ni mucho menos masonería, como algunos, haciendo una ilógica e incomprensible transpo-

(55) Cfr. nota 45.

(58) Seco Serrano, ob. cit., p. XXVII. Repite la misma argumentación en su estudio La época de Carlos IV, estudio preliminar a la Historia de Carlos IV de A. Muriel, Madrid, B.A.E., 1959, y en Godoy el hombre y el politico, Madrid, Espasa-Calpe, 1978. 
sición decimonómica, han aplicado al término «cábala» o simplemente al de «sociedad».

Por pcco que se conozca la Historia de este período, y sobre todo la biografía del conde de Aranda y del «partido aragonés», resulta insostenible la interpretación anterior, basada no ya sólo en una transposición ideológica de lo más acientífica, sino - lo que es más grave - en una lamentable confusión de la terminología del siglo XVIII, al pretender identificar "cábala» con masonería, siendo así que las «sociedades» a que alude el diálogo en cuestión, no apuntaban a otra cosa que a la «facción» del «partido aragonés» que durante la ausencia de Aranda, se había refugiado en el cuarto de los Príncipes de Asturias, desde donde actuaron en tiempos de Carlos III, como luego lo harían, igualmente, en tiempos de Carlos IV ( $\left.{ }^{57}\right)$.

Ha sido sobre todo la historiografía de la segunda mitad del siglo XIX, la que más ha falsificado - con un simplismo sólo superado por su proprio desconocimiento de la Historia este período de la vida política de Aranda. Por ejemplo, Delbrell escribe en 1889 (y aquí la fecha es muy importante), que la oposición que hizo Aranda en 1793 a la declaración de guerra, y en 1794 a la continuación de la lucha antirrevolucionaria, fue debida a ser Aranda "no solamente francmasón, sino uno de los jefes de la secta». La explicación - añade - radica en este punto «más bien que en los diversos considerandos invocados por él, en el Consejo de Estado, en el curso de la discusión que le trajo su desgracia» $\left({ }^{58}\right)$.

Como puede verse, se trata de una nueva identificación de hechos muy distintos, y sin la menor conexión unos de otros. Es una vez más el embajador austríaco, quien, en sus despachos posteriores al destierro de Aranda, después de aludir a la agitación que - se decía - iban a provocar los partidarios de Aranda, a causa de su destierro, nos describe quiénes eran, para esas fechas, los tales partidarios del conde. En primer lugar dirá, que eran «bastante numerosos», y que estaban repartidos por casi todos los estamentos, en especial entre los «funcionarios de asuntos extranjeros», así como entre «la mayor parte de los empleados más viejos de los ministerios, favorecidos en la intimidad por el conde de Aranda». A éstos había que añadir la camarilla de los abogados, y gran parte de los militares $\left({ }^{59}\right)$.

(57) Cfr. nota 29.

(58) J. Delbrell, "L'Espagne et la Révolution française; la diplomatie revolutionnaire. Le comte de La Union», Etudes, XLVII (1889) 251.

(59) Cfr. nota 45. 


\section{Los partidarios de Aranda}

La caída de Aranda fue seguida de una serie de pesquisas, encaminadas a descubrir y anular el influjo de los partidarios del conde. Sin embargo, unos meses más tarde - a primeros de julio -, todas las investigaciones emprendidas acerca de importantes personas fueron en cierto modo sobreseídas. En esta ocasión, la Reina influyó - en contra del parecer, no ya del Gobierno, sino del propio Rey -, quien estaba inclinado en este negocio a la clemencia. Sin embargo, la Reina quería que se prosiguieran las investigaciones con el mayor rigor, según informa von Kageneck. De hecho, el conde de Aranda y su familia no se vieron beneficiados de esta amnistía, ya que, como indica el embajador austríaco, «contra el conde de Aranda prosiguen las investigaciones secretas, y precisamente hace un par de noches se hicieron a su esposa y servidumbre diversas preguntas, para que respondieran a ellas».

Pero, a los cuatro meses del destierro de Aranda, la preocupación manifestada por Kageneck se centró en el descubrimiento - hecho precisamente a raíz de las investigaciones, que había mandado sobreseer el Rey - de que «se había visto claro que el número de los descontentos con el Ministerio era mucho mayor de lo que se podía esperar, y que incluso muchos de los empleados más considerables eran adictos al plan del conde de Aranda». Nueva constatación de la amplitud del partido de Aranda, o al menos de aquellos que comulgaban con su política pacifista. Esta política, o "plan del conde de Aranda», iba enfocado - según escribe Kageneck - a poner fin a la actual guerra, a derrocar al Ministro, y a emplearse en una mejor organización del gobierno interior, que había de ser desempeñado únicamente por medio de la convocación de las Cortes. Pero a lo que se dirigía la verdadera intención era: a la reducción del poder real, a la supresión de la Inquisición, $\mathrm{y}$, sobre todo, a la disminución del clero, todo lo cual podría desembocar, en este Reino, en una revolución de Estado" $\left({ }^{(00}\right)$.

Como se ve, el plan de Aranda se reducía a poner fin a la guerra contra los franceses, y a una organización del Gobierno interior, por medio de una mayor democratización que acortara los campos de influencia y de poder del propio Rey, de la Inquisición y del Clero. Entre los adictos a este plan - y esto es lo que parece extrañar a Kageneck - «se encontraban no sólo los abogados, y la así llamada clase intelectual, sino

(60) Ibidem. 


\section{Revista de História das Ideias}

incluso el Ejército, donde los viejos generales y oficiales - escribía - están casi todos descontentos, mientras que los jóvenes por el contrario, en parte son ineptos para el servicio, y el resto está inficcionado por los principios franceses». A los pocos meses de la eliminación de Aranda del campo político, se constata que, en la soledad de su destierro, el anciano conde estaba acompañado afectiva e ideológicamente por un gran número de partidarios, que abarcaban todos los estamentos sociales, desde la mayor parte de los empleados ministeriales, la poderosa camarilla de los abogados «togados» y la clase intelectual, hasta los propios Ministros y el Ejército, donde contaba con la adhesión de casi todos los generales y oficiales, tanto en activo como en retiro.

Poco después, a mediados de julio, se puso de manifiesto una vez más - según se deduce de la información facilitada por Kageneck - cómo la Reina y Godoy se salieron con la suya, incluso en oposición al deseo del rey, en su deseo de seguir persiguiendo a los partidarios de Aranda. «A pesar de una más suave solución propuesta por el rey, - escribía el austríaco - ha surgido un nuevo motivo para investigaciones secretas y detenciones». Consecuencia de esta nueva persecución de los partidarios de Aranda fue, "por una parte, la inquietud resultante para muchos que pensaban bien, y por otra, el endurecimiento en el modo de pensar de aquellos que deseaban el exterminio del Ministro, verdaderamente cada día más odiado».

Después de esta elocuente constatación, de la antipopularidad de Godoy, que era cada día más odiado, von Kageneck vuelve a ocuparse del plan de Aranda, conducente a convertir las Cortes en algo semejante a una Convención Nacional, en detrimento de la autoridad real. «No obstante - decía - no se tiene corazón para proceder contra este Conde como él se merece, por temor a sus más bien numerosos partidarios». Y por lo visto, con el fin de cortar toda posible comunicación del desterrado con estos partidarios que, como subraya Kageneck, eran más bien numerosos, fueron dadas «nuevamente órdenes de vigilar al mismo de cerca en su destierro, y de que no se le permitiera correspondencia alguna, sin que todas las cartas por él escritas y recibidas fueran sometidas al comandante de Jaén ${ }^{\left({ }^{61}\right) \text {. }}$

A lo largo de los informes del embajador austríaco, hay una tendencia a identificar a los partidarios de Aranda (cada vez más numerosos a pesar del destierro de su jefe), con los «descontentos». A partir del despacho del 22 de julio de 1794,

(61) Ibidem . 


\section{El Conde de Aranda}

este «número de descontentos», que - según Kageneck - había aumentado en estos últimos tiempos, viene a incrementarse "con muchos Grandes y con personas considerables». Esta vez, la aversión de los Grandes era debida, también, «al desagrado que les causaba el extraordinario encumbramiento del Ministro (Godoy) y de sus parientes». Pero sobre todo, «su odio contra el Ministro era mayor, y aumentaba, a causa de su manifiesto proceder en relación con el conde de Aranda ya que proseguían las investigaciones secretas contra el mismo; y el destierro, sin notificación de su crimen se consideraba como ilegal y ponía a todo el mundo en sobresalto».

Esta última frase, en la que se señala que el destierro de Aranda era considerado como ilegal, puede dar luz al tan debatido Consejo del 14 de marzo, que provocó el alejamiento del conde. Lo que en aquel Consejo sucedió fue únicamente la excusa para llevar a cabo la eliminación de un sujeto peligroso, - de la misma forma que se iban eliminando todos los partidarios de Aranda. La necesidad de su destierro se fue imponiendo para la política de la Reina y su Ministro. Faltaba la ocasión. Y una vez desterrado, era necesario un último paso: encontrar motivos que justificaran tal medida. De ahí las investigaciones secretas, el requisarle los papeles con objeto de hallar algo ccmprometedor, el hacerle fautor de una abortada revolución, el acusarle de un acuerdo secreto con los franceses, o simplemente el que se pidiera su entrega a la Inquisición, pues - como escribe Kageneck el 22 de julio - «es muy cierto que siempre se han notado en él peligrosos principios contra la Religión». Respecto a estos "principios peligrosos contra la Religión», el propio Kageneck aclaraba que lo único que pretendía Aranda era disminuir el influjo politico del clero, lo cual no tiene nada que ver con la verdadera Religión.

Pero, por lo visto, ninguno de estos «crímenes» - reales - supuestos - tenía suficiente peso, y el destierro de Aranda seguía siendo considerado como ilegal ante la nación. No deja de ser curioso que ni una sola vez se le acusara entonces de masón, - como luego hicieron, con una gran dosis de ignorancia histórica, ciertos «historiadores masones, como antimasones, e incluso universitarios» - tanto más cuanto que ser masón era un crimen de lesa majestad, y estaban en pleno vigor las leyes civiles y eclesiástico-inquisitoriales, contra dicha asociación.

Conforme pasaban los días, los partidarios de Aranda aumentaban todavía más, pues, como comunicó von Kageneck desde San Ildefonso el 5 de agosto de 1794, los únicos adictos a la política de la Corte - que esta vez identificaba con «la 
Religión y el Rey» - eran el clero y los campesinos. Al lado de Aranda estaban ahora la nobleza y los habitantes de las ciudades, que habían pasado a engrosar el grupo de los ya mencionado abogados, de la clase intelectual, de los militares, los funcionarios de los Ministerios, y los Grandes de España, a los que se añadirán, en el despacho del 15 de noviembre, «los comerciantes y muchos Ministros» $\left({ }^{62}\right)$.

\section{La razón de Aranda}

Finalmente, Aranda iba a triunfar desde su destierro en su idea política pacifista. El 15 de octubre de 1794 comenzaron las negociaciones oficiales de paz. De haberse realizado éstas cuando el conde de Aranda y sus partidarios las propusieron - ya en febrero de 1794 - todavía existiría «la posibilidad de poder concertar con los franceses una honrosa paz ventajosa para España, en la que se contaría con la cesión de la parte francesa de la isla de Santo Domingon. Sólo que, no se podía poner en duda, que en aquellas fechas «las intenciones del duque de Alcudia eran contrarias a este parecer». Ahora bien, el 25 de noviembre, el mismo embajador austríaco reconocía, desde El Escorial, que a estas alturas «a lo más, sólo podría conseguirse esa paz por medio de sacrificics, lo cual era patente a todos en las presentes circunstancias».

Como medio de reducir los sacrificios, propuso el embajador de la Corte de Viena que «debería ser decretada en el Gabinete la conquista de la parte francesa de Santo Domingo, para que pudiera servir a su tiempo de cambio con las provincias españolas "ocupadas por los franceses». Obsérvese que, ya el 24 de febrero, tanto Aranda como sus partidarios reconocían entonces la conveniencia, y la posibilidad, de «concertar con los franceses una honrosa paz, ventajosa para España, en la que se contaría con la cesión de la parte francesa de la Isla de Santo Domingo». Ahora era ya demasiado tarde; las tornas habían cambiado, y a lo único que se podía aspirar era a la reconquista de la «parte francesa de Santo Domingo, para que pudiera servir a su tiempo de cambio con las provincias españolas, ocupadas ahora por los franceses». Por el Tratado de $\mathrm{Paz}$ entre la República francesa y el Rey Católico, firmado en Basilea el 4 del mes de Termidor del año 3. ${ }^{\circ}$ de la República ( 2 de julio de 1795), ésta restituía a España todas las conquistas hechas en el curso de la guerra, en tanto que Carlos IV

(82) Ibidem. 
concedía a Francia la parte española de Santo Domingo. De esta forma, por no haber sido escuchado a tiempo a Aranda, España no sólo no recobraba la parte francesa de la isla, sino que perdía incluso la parte española. Por desgracia, el destino había dado una vez más la razón a Aranda.

Godoy hubo de reconocer que la guerra contra la República francesa, además de ser un fracaso militar, arriesgaba la Monarquía que pretendía defender, siendo a la vez ruinosa y superior a nuestras fuerzas. Es decir, que acabó esgrimiendo los mismos argumentos, que tantas veces había dictado Aranda en contra de la guerra, y que fielmente mantuvo «el poderoso partido arandista».

El precio que tuvo que pagar Godoy para superar este fracaso costó muy caro a España. Pero ello no impidió que, con este motivo, al convertirse en aliado de la Revolución, se adjudicará él mismo el más alto título, el de Príncipe de la Paz. Lo paradógico en este caso es que Godoy, que día a día mantuvo su empeño belicista y su oposición a cualquier idea de paz - como se puede apreciar a lo largo de la correspondencia del embajador de Viena - , acabará ostentando el título de la $\mathrm{Paz}$, en tanto que Aranda, que se opuso hasta la «autoinmolación» de su persona a esta guerra, y que siempre abogó por una actitud pacifista, recibió como premio el destierro y el olvido.

\section{Reflexión final}

La historia política española de 1789 a 1795 es la del conflicto entre dos familias de espíritu, los don Quijote y los Sanchos Panza. Los que quieren evitar a su país una guerra, de resultado incierto, y los que sueñan con una cruzada contra la Revolución. A su vez, la historia militar de la península añade a su historial un nuevo episodio. de la épica lucha que España ha ido manteniendo durante décadas, en defensa de los valores tradicionales.

Muchos fueron los Quijotes, aunque, en verdad, tampoco escasearon los Sanchos. Peron, al igual que en el libro cervantino, el caballero del honor - el que actuaba a impulsos de «razones ideales» - acabó siendo vencido por el escudero del sentido común - el que veía las cosas a través de «razones reales». Godoy, el paladín oficial de la causa real, hubo de reconocer que la guerra contra la República francesa, además de ser un fracaso militar, arriesgaba a la Monarquía que pretendía defender - contagiada ya de las ideas revolucionarias -, siendo 
a la vez ruinosa y superior a nuestras fuerzas; es decir, que acabó esgrimiendo los mismos argumentos que tantas veces había dictado Aranda en contra de la entrada en guerra.

Pero Godoy, el caudillo de la reacción monárquica, recibía en premio de su «fidelidad», al convertirse en aliado de la Revolución, el más alto título, el de Príncipe de la Paz. En tanto que el político hábil, que previó los males de la patria y propuso al Rey evitarlos, el «escudero» que desenmascaró las intenciones inglesas, y que, cuando creyó tener razones auténticas, sugirió y preparó la lucha; el que, a su vez, cuando cambiaron las circunstancias juzgó no sólo conveniente sino necesario el cese de la guerra; el que solamente por haber dado este consejo fue tratado de mal vasallo, éste, recibía en premio el olvido y el destierro. $\mathrm{Y}$ es que Aranda estuvo dotado de un agudo olfato político que le obligaba a actuar siempre con vistas al futuro; éste fue su sino, y éste fue también su daño y perdición.

No hace falta que recurramos al «volteriano», ni al «jacobino» o «masón» Aranda, y ni siquiera al «impío perseguidor» de los jesuítas, para comprender su postura frente a los revolucionarios franceses; basta con descubrir en él al hombre que prefería mantener fiel a la metrópoli al pueblo sudamericano, antes que embarcarse en una aventura de interesses manejados por manos británicas; basta con saber captar su amor a la patria.

La política de Aranda en su relación con la Francia revolucionaria está basada en unos móviles no tanto profranceses cuanto antibritánicos, $\mathrm{y}$, sobre todo, eminentemente españoles. 